\title{
A Socio-Economic Linkage of Urban Informal Sector to Formal and Other Informal Sectors in Hawassa Town: Intensifying Growth from the Street
}

\author{
Habtamu Tolera \\ Department of Geography and Environmental Studies, College of Social Sciences, \\ Post Box No: 395, Wollega University, Nakemte, Ethiopia
}

\begin{tabular}{|c|c|}
\hline Abstract & Article Information \\
\hline \multirow{10}{*}{$\begin{array}{l}\text { A comprehensive survey pertaining to vendors and the role vendors' play in } \\
\text { economic links between urban informal and formal sectors in Hawasa town is not } \\
\text { studied so far. Hence, the main purpose of this study has been to identify major } \\
\text { vendor activities and examine the types and intensification of socio-economic } \\
\text { linkages these vendor activities do have with formal and other informal sectors to } \\
\text { stimulate growth in the country in general and in study town in particular. To this } \\
\text { end, it had an overall objective of proposing viable government policy interventions } \\
\text { aimed at enhancing the productivity and socio-economic intensification of vendor } \\
\text { operations. In order to achieve this objective a sample of } 140 \text { street vendors were } \\
\text { selected from parent population and relevant data were gathered mainly through } \\
\text { questionnaires and analyzed using cross tabulations and percentages. The survey } \\
\text { revealed the transfer of resource in the form of wage from wage earners to street } \\
\text { vending, consumption linkage. The study also found that there was nearly no closer } \\
\text { linkage between vendor enterprise and formal financial institutions. The latter lent } \\
\text { little loans to street enterprise owners. }\end{array}$} & $\begin{array}{l}\text { Article History: } \\
\text { Received : } 13-02-2013\end{array}$ \\
\hline & Revised : 29-03-2013 \\
\hline & Accepted : 30-03-2013 \\
\hline & $\begin{array}{l}\text { Keywords: } \\
\text { Forward Linkage }\end{array}$ \\
\hline & Backward Linkage \\
\hline & Formal Sector \\
\hline & Informal sector \\
\hline & ${ }^{*}$ Corresponding Author: \\
\hline & Habtamu Tolera \\
\hline & E-mail: habtol@yahoo.com \\
\hline
\end{tabular}

\section{INTRODUCTION}

One of the most important characteristics of informal activities is that the capacity they have to stimulate growth in other sector (Getachew, 1994; Etsigenet, 2004). Formal and informal sectors operate variety of linkages of several forms such as the flow of inputs in the form of material resources, labor, and technology and out puts in the form of finished and semi finished consumable and non-consumable goods or services between the two sectors. The growth potential of the micro-informal enterprises critically depends on the formal sector (ILO, 1984). Getachew (1994) in his study of dynamics of linkages entails the flow of inputs such as raw materials, machines, equipment etc. to the informal enterprises. He investigates the flow of inputs into informal tailoring enterprises from the formal enterprises in the form of textile, threads, scissors, buttons and other inputs. There is also reverse links which is expressed in terms of inputs sales from informal to formal enterprises. The ILO studies (1984) and (1985) stated that there is again expressed when household earnings from formal sector consume informal sector products. This study also entails the flow technologies in the form of equipment, know how, and skilled persons between formal and informal economies.

Some writers such as Jellinek and Todaro (1994) agreed that most of informal operators obtain their merchandise from the formal sectors and markets. Getachew (1994) accepts these authors' idea and in his study of the dynamics of linkage (1994), he declared the informal tailoring enterprises buy their inputs from intermediary of the licensed dealers and this is economic linkages in the form of inputs. According to Todaro (1981) there is a strong linkage of informal enterprises with the rural economy and 


\section{Habtamu Tolera}

through this interaction the informal sector allows excess labor to escape from rural poverty and underemployment. Rempel (1996) agrees with Todaro's idea and argued that rural exodus in major cities of Third World countries are absorbed by the informal micro-enterprises. Other writers like Hart (1991), and McGee and Yeung (1977) suggested the informal sector including street hawking as a point of entry for the new migrants from rural areas into working life of the city". These all indicated the labor mobility between the two sectors specially labor flow from formal to informal sectors and from informal to formal sectors.

Robert (1989) argued that there is strong evidence of systematic linkages between formal and informal sectors following the equipment of profitability. According to them "workers may switch between the two sectors during the same work day with a unionized machinist moonlighting as a plumber while a secretary does key punching at home in her off duty time" (Etsegenet, 2000; Tesfaye, 1999; Azeb,1998; Robert,1989). According to ILO (1991), an informal enterprise subsidize cheap goods and services for the formal sector and provides cheap goods and services for the formal sector workers.

Webister and Fiddler (1996) in their studies of informal sector enterprises in West Africa indicate the weak transfer of resources from informal to formal enterprises. They showed over 70 per cent of informal enterprises in this region have no forward linkages with the formal sector. Similarly, in Tanzania the informal enterprises sell almost over two-thirds of goods and services to the local poor consumers (Bagachaw, and Lauanga, 1993; De Seto, 1989; Mc Gee, 1986; Brommley, 1997). Fowler (1981) also agrees with the author's findings. In his survey study in Freetown, he finds out 81 per cent of the businesses sold almost exclusively to individuals and households. Only 1.1 per cent sold their goods and services to big businesses. This is also true in the case of Ethiopia. In his studies of dynamics of linkages, Getachew (1994) investigates the informal tailoring enterprise sell little to formal enterprise.

There were a large number of informal sectors running business without license out of which 24 wholesale trades, 591 retailers, 356 service providers, 100 small scale industries and one farm in Hawasa town (CSA, 2004 and 2000). However, there was no any information about the types and degree of linkages that is organized about the Informal and formal activities in the city though the aforementioned rough data about the existence and types of activity were roughly estimated by Trade and Industry Office of the
Sci. technol. arts Res. J., Jan-Mar 2013, 2(1): 95-102

town in 2012. Thus, the informal and formal linkages of the urban economy of the town in particular and the country in general could be described and known for lack of data. This is due to the absence of well-conducted research work in the area under investigation.

Despite theoretical differences among scholars, the informal sector will continue to play a role in the immediate future. Therefore, policies for intensifying the linkages between the two sectors would be taken into account to raise especially incomes and employment among informal enterprises by intensifying the socioeconomic links between the sectors. A wise policy issues should not worry about links is benign, exploitative or mutually beneficial but enhances the positive linkages and to ensure that there is a decent work all along the continuum (Granstrom, 2009; Martha, 2007; McGee, 1986; Moser, 1978). The researcher aimed at to investigate different forms of informal enterprises and the types and intensity of socio-economic linkages exist between these small business ventures in the study area and finally, to recommended policy options to intensify the economic linkages of the enterprises so as to stimulate growth, income and employments of the urbanite.

\section{MATERIALS AND METHODS}

The target population is informal sector operators in Hawasa town. There were over twenty seven thousands informal operators engaged in the sector in the city. A total of 438 operators were found to be engaged in different enterprises and then manageable sample population was determined as 32 percent of a total giving a sample size of 140 . Hence, sample enterprises were drawn using a stratified random sampling procedure and proportional sampling fraction. The former was used because the population to be sampled was heterogeneous while the latter was preferred to obtain sample number that was proportional to each stratum size in the population. Eventually, representative respondents were randomly selected from two main areas, i.e. 'Menaheria' and "Piassa" and approached for interview The 'Menaheria' area is selected as it is expected to hold a large number of street-vendors who are attracted by the relatively large passing trade generated by its proximity to bus terminus and 'Piassa' area is the center of the town and major private shopping areas.

A Number of research techniques are used in gathering the required data. These include questionnaire and review of official documents, 
Habtamu Tolera

books, proceedings, journals, various publication, web sites. The main body of information, primary data, was collected through questionnaire to the street vendors. It contains type of vendors' operations and the nature of linkages that exist in terms of initial capital, credit, wage, purchase, sale and labor mobility with other sectors.

The questionnaire was carefully designed and structured based on the objective of the study. It was first designed in English and then translated in to Amharic so that the enumerators may use it. Ten interviewers were selected on the bases of their personal characteristics and educational level (all are high school graduates). They were given a two days training on the nature and details of the questionnaire as well as on the procedures they should follow while conducting the interview. A pilot survey consisting of 15 vendors (11 percent of the total sample) was conducted to pretest the questionnaire. Changes were made in the design of some of the questions on the bases of the results of the pretest before embarking on the survey. The secondary data used in this study were different official documents like books, proceedings, journals, various publication, web sites, etc on the subject of informal sectors and street vending.

Both qualitative and quantitative methods of data analysis were used. The first stage of data analysis comprised the preparation of code books for the questionnaires. The questionnaires were edited, coded, and analyzed using the (SPSS) computer programs. The quantitative techniques utilized in this study were cross tabulations and frequency percentages. Tables, figures and graphs were also used employed.
Sci. technol. arts Res. J., Jan-Mar 2013, 2(1): 95-102

\section{RESULTS AND DISCUSSION}

A new set of issues that were examined relate to the nature of linkages between vendors activities and the modern urban formal and informal sectors, on the one hand, and between vendor activities and the rural agriculture, on the other hand (Table 1). In this respect, source of initial capital, source of inputs, destinations of final products, loans secured, wage and source of labor were taken as important indices of linkage.

\section{Backward Linkage by Source of Initial Capital}

With respect to initial capital, there was some closer backward linkage between vending industries and formal and informal sectors (Table 1). $56.1 \%$ of vendor entrepreneurs obtained their initial capital from formal sector. In other words, about $29.5 \%, 9.5 \%$ and $9.0 \%$ of vendor respondents indicated sales of farm produce, previous wage and income from modern enterprise to set up their street business profession. Some $5.2 \%$ with money obtained from parent's salary while $2.9 \%$ noted credit from formal financial institutions. Indeed between these formal sector units differences also emerge. The majority of vendors were more linked with rural agricultural produces but their backward linkages with formal financial institutions and wages were very low. On the other hand, $22.9 \%, 11.0 \%$, and $10.0 \%$ of vendor entrepreneurs obtained their initial capital from informal sector units such as informal sector enterprises, informal moneylenders and traditional institutions like "Iqub" respectively. This denotes that $43.9 \%$ of vendors began their street businesses with capital secured from other informal activity and financial institutions. This would be termed as intra-sectorial flow of capital within informal economy.

Table 1: Distribution of Backward Linkages by Source of Initial Capital.

\begin{tabular}{|c|c|c|c|c|c|c|c|c|}
\hline \multirow[t]{2}{*}{ Sector } & \multirow[t]{2}{*}{ Source } & $\begin{array}{l}\text { Fruit \& } \\
\text { Vegetable }\end{array}$ & $\begin{array}{c}\text { Second } \\
\text { Hand } \\
\text { Cloth } \\
\end{array}$ & $\begin{array}{l}\text { Bicycle } \\
\text { Service }\end{array}$ & $\begin{array}{l}\text { Prepared } \\
\text { Food }\end{array}$ & $\begin{array}{l}\text { House } \\
\text { Hold } \\
\text { Goods }\end{array}$ & $\begin{array}{c}\text { Miscella } \\
\text { neous } \\
\text { activities }\end{array}$ & Total \\
\hline & & $\%$ & $\%$ & $\%$ & $\%$ & $\%$ & $\%$ & $\%$ \\
\hline \multirow{5}{*}{ Formal } & Sales of farm produce & 30.6 & 33.3 & 22.0 & 35.4 & 33.4 & 30.8 & 29.5 \\
\hline & Previous wage & 4.20 & 7.0 & 17.0 & 08.3 & 7.7 & 5.1 & 9.5 \\
\hline & Parent private enterprise & 5.60 & 14.1 & 6.5 & 18.8 & 12.8 & 15.5 & 9.0 \\
\hline & Parent salary & 9.60 & 2.0 & 4.9 & 06.3 & 5.1 & 5.1 & 5.2 \\
\hline & $\begin{array}{l}\text { Loans from formal } \\
\text { institution }\end{array}$ & 5.60 & 4.0 & - & 02.0 & 5.1 & 2.6 & 2.9 \\
\hline \multirow{4}{*}{ Informal } & $\begin{array}{l}\text { Income from other } \\
\text { informal enterprise }\end{array}$ & 20.8 & 21.2 & 25.2 & 18.8 & 23.1 & 28.2 & 22.9 \\
\hline & Informal moneylenders & 13.9 & 5.0 & 11.4 & 10.4 & 7.7 & 2.6 & 11.0 \\
\hline & "Iqub" & 9.70 & 13.1 & 13.0 & - & 5.1 & 10.3 & 10.0 \\
\hline & Total & 100 & 100 & 100 & 100 & 100 & 100 & 100 \\
\hline
\end{tabular}


Habtamu Tolera

When specific vendor activities were viewed independently, the largest proportion of fruit and vegetable sellers, secondhand cloth sellers, prepared food sellers, household goods sellers and "miscellaneous" vendors also mentioned sales of farm produce as their source of finance to set up their street occupations. Over all, the degree of transfer in the factor market, i.e. initial capital was withdrawn a few economic units. It was more pronounced with farm and informal sector enterprise incomes.

\section{Backward Linkages by Origin of goods or Services Delivered}

Table 2 reveals backward linkage of street vending to formal and informal sectors. Formal sector supplies raw materials to vendor enterprises. Seventy five percent $(75.0 \%)$ of respondents obtained their goods or services from formal sector units. In other word, $36.9 \%$,
Sci. technol. arts Res. J., Jan-Mar 2013, 2(1): 95-102

$30.7 \%, 5.7 \%$, and, $1.7 \%$ of vendors obtained their goods or services from formal private enterprises, licensed wholesalers/ retailers, government enterprise and farmers/producers, respectively. This indicates flow of inputs from formal sector to vendors' activities. However, the degree of transfer was different across formal activities. It was less prominent the case of farmers /producers and government enterprises but more pronounced in terms of modern private enterprises and licensed wholesalers/ retailers. However, the backward linkage with the latter was invasive and this was a problem. Vendors purchased goods or services from these intermediaries. They did not have a direct access to manufactures. Such a chain of supply of inputs raised the cost of vendor operations, down turned their profit margins and sending the less competitive firms out of business.

Table 2: Backward linkages by types of activities and source of goods or services.

\begin{tabular}{|c|c|c|c|c|c|c|c|c|}
\hline \multirow[t]{2}{*}{ Sector } & \multirow[t]{2}{*}{ Source } & $\begin{array}{c}\text { Fruit \& } \\
\text { Vegetable }\end{array}$ & $\begin{array}{l}\text { Second } \\
\text { Hand } \\
\text { Cloth }\end{array}$ & $\begin{array}{l}\text { Bicycle } \\
\text { Service }\end{array}$ & $\begin{array}{l}\text { Prepared } \\
\text { Food }\end{array}$ & $\begin{array}{c}\text { House } \\
\text { Hold } \\
\text { Goods }\end{array}$ & $\begin{array}{l}\text { Miscella } \\
\text {-neous } \\
\text { Activities }\end{array}$ & Total \\
\hline & & $\%$ & $\%$ & $\%$ & $\%$ & $\%$ & $\%$ & $\%$ \\
\hline \multirow{4}{*}{ Formal } & $\begin{array}{c}\text { Formal private } \\
\text { enterprise } \\
\text { Licensed }\end{array}$ & 22.2 & 48.5 & 50.4 & 27.1 & 25.6 & 15.3 & 36.9 \\
\hline & $\begin{array}{l}\text { wholesalers/ } \\
\text { retailers }\end{array}$ & 23.6 & 30.3 & 30.1 & 16.7 & 53.6 & 41.0 & 30.7 \\
\hline & $\begin{array}{l}\text { Government } \\
\text { enterprise }\end{array}$ & 8.4 & 7.2 & 4.9 & 2.0 & 2.6 & 7.7 & 5.7 \\
\hline & $\begin{array}{l}\text { Farmer or } \\
\text { producer }\end{array}$ & 33.3 & - & - & 39.6 & 2.6 & 2.6 & 1.7 \\
\hline \multirow{3}{*}{ Informal } & $\begin{array}{l}\text { Informal sector } \\
\text { enterprise }\end{array}$ & 12.5 & 11.0 & 12.2 & 10.4 & - & 30.8 & 21.4 \\
\hline & Own produce & - & 3.0 & 2.4 & 4.2 & 15.6 & 2.6 & 3.6 \\
\hline & Total & 100 & 100 & 10 & 100 & 100 & 100 & 100 \\
\hline
\end{tabular}

The remaining $25.0 \%$ of surveyed vendors obtained their supplies from other informal sector units, i.e. $21.4 \%$ purchased from other informal enterprises and $3.6 \%$ used own produce such as own garden produce and handcrafts work. A recent survey collaborates this finding. For example, according to Getachew (1994) when faced with shortage of raw materials, informal firms resort to other informal establishments. However, unlike the backward linkage with formal sector, the flow of transfer from informal to street vendor operations was less pronounced. The difference also emerged among vendor activities. For instance, prepared food and fruits and vegetable vendors' activities have a strong backward linkage with producers / farmers. About $39.6 \%$ and $33.3 \%$ of these enterprises purchased their merchandises for their stalls from immediate agricultural hinterlands respectively. Farming, in this respect constitutes other income-generating activity and provided the bulk of inputs. The transfers were, for example, in the form of raw materials such as apples, banana, orange, potatoes in the case of fruit and vegetable hawking and teff, barley, wheat, maize, etc in the case of prepared food hawkers. Hence, backward linkage was direct and prominent in linking rural agricultural sector with urban street vending industry.

\section{Backward Linkage by Source of Borrowed Fund}

Economic linkage is also expressed in terms of credit loans transferred from formal financial institutions. Formal financial institutions had nearly no closer linkages with vendor enterprises 


\section{Habtamu Tolera}

and they lent very small loans to them (Table 3). Out of the total sampled population, only $1.4 \%$ vendors obtained credit from macro-financial institution, i.e. commercial bank of Ethiopia. Some $7.9 \%$ and $5.7 \%$ borrowed from Omo and Sidama micro-credit institutions respectively. The total amount of loans lent for vendors was very small. It was only 15,100 Ethiopian Birr. The remaining $85.0 \%$ obtained no loans. Asked vendors to state the major obstacles faced them to secure loans from such institutions, $88.4 \%$ said no collateral and $6.6 \%$ cited of small transaction size. The remaining proportion stated the lack of legality of their physical space and
Sci. technol. arts Res. J., Jan-Mar 2013, 2(1): 95-102

lack of bookkeeping. Thus, intersectoral backward flow of resources from formal institution to informal economy, vendor enterprises, was almost non-existent. This problem is reflected in the heavy dependence of the sector on nonformal institutional credit to run businesses. Almost all vendors' financial transactions take place with family and friends and informal savings like "lqub" and moneylenders. Relatively speaking, however, the flow of micro-loans from micro-credit institutions like Sidama and Omo a little bite recognized the importance of backward linkage between formal institutions and vendor activities.

Table 3: Backward linkage by types of activities and credit from formal institutions.

\begin{tabular}{|c|c|c|c|c|c|c|c|c|c|c|c|c|c|c|}
\hline \multirow{2}{*}{$\begin{array}{c}\text { Formal } \\
\text { institutions }\end{array}$} & \multicolumn{2}{|c|}{$\begin{array}{l}\text { Fruit and } \\
\text { Vegetable }\end{array}$} & \multicolumn{2}{|c|}{$\begin{array}{c}\text { Secondh } \\
\text { and } \\
\text { Cloth }\end{array}$} & \multicolumn{2}{|c|}{$\begin{array}{l}\text { Bicycle } \\
\text { Service }\end{array}$} & \multicolumn{2}{|c|}{$\begin{array}{l}\text { Prepared } \\
\text { Food }\end{array}$} & \multicolumn{2}{|c|}{$\begin{array}{c}\text { House } \\
\text { Hold } \\
\text { Goods }\end{array}$} & \multicolumn{2}{|c|}{$\begin{array}{c}\text { Miscella } \\
\text { neous } \\
\text { ctivities }\end{array}$} & \multicolumn{2}{|c|}{ Total } \\
\hline & No & $\%$ & No & $\%$ & No & $\%$ & No & $\%$ & No & $\%$ & No & $\%$ & No & $\%$ \\
\hline $\begin{array}{c}\text { Commercial } \\
\text { bank }\end{array}$ & - & - & - & - & 2 & 4.9 & - & - & - & - & - & - & 2 & 1.4 \\
\hline $\begin{array}{l}\text { Omo micro- } \\
\text { finance }\end{array}$ & 3 & 12.5 & - & - & 5 & 12.2 & 2 & 12.5 & 1 & 7.7 & - & - & 11 & 7.9 \\
\hline $\begin{array}{c}\text { Sidama } \\
\text { micro-finance }\end{array}$ & 2 & 8.2 & - & - & 6 & 14.6 & - & - & - & - & - & - & 8 & 5.7 \\
\hline No borrowed & 19 & 79.2 & 13 & 100 & 28 & 68.3 & 14 & 87.5 & 12 & 93.3 & 13 & 100 & 11.9 & 85 \\
\hline Total & 24 & 100 & 13 & 100 & 41 & 100 & 16 & 100 & 13 & 100 & 13 & 100 & 140 & 100 \\
\hline
\end{tabular}

Distribution of Forward Linkages by Markets for Final Produces

Forward linkage is expressed in terms of sales from informal to formal sector enterprises (Granström, 2009; Getachew, 1994; Fowler, 1981). The results were presented in Table 4. Unlike backward linkages, the formal and the informal forward linkages of enterprises with vendor operations were negligible. Vendors sell little to formal and informal sector enterprises. $72.2 \%$ of the respondents reported they sold their goods or service directly to individual households. About $19.3 \%$ supplied to formal private enterprises. Only a small proportion of $1.4 \%$ was to wholesalers/retailers and $7.1 \%$ to other informal sector units and none of vendor entrepreneurs sold to public enterprise. Thus the bulk of vendors' goods or services were sold to end users/ individual households and this denotes that predominant consumption linkage. It is interesting to note a much larger proportion of the vendor entrepreneurs sold their goods or services to individual and households suggesting that most of informal sector dealt in goods or services consumed daily and the majority of street traders could be found in this category.

Table 4: Forward linkages by types of activities and destination of vendors' final goods or services.

\begin{tabular}{|c|c|c|c|c|c|c|c|c|c|c|c|c|c|c|}
\hline \multirow{2}{*}{ Source of Demand } & \multicolumn{2}{|c|}{$\begin{array}{c}\text { Fruit \& } \\
\text { Vegetable }\end{array}$} & \multicolumn{2}{|c|}{$\begin{array}{c}\text { Second } \\
\text { Hand } \\
\text { Cloth }\end{array}$} & \multicolumn{2}{|c|}{$\begin{array}{l}\text { Bicycle } \\
\text { Service }\end{array}$} & \multicolumn{2}{|c|}{$\begin{array}{l}\text { Prepared } \\
\text { Food }\end{array}$} & \multicolumn{2}{|c|}{$\begin{array}{c}\text { House } \\
\text { Hold } \\
\text { Goods }\end{array}$} & \multicolumn{2}{|c|}{$\begin{array}{c}\text { Miscella } \\
\text { neous } \\
\text { Activities }\end{array}$} & \multicolumn{2}{|c|}{ Total } \\
\hline & No & $\%$ & No & $\%$ & No & $\%$ & No & $\%$ & No & $\%$ & No & $\%$ & No & $\%$ \\
\hline $\begin{array}{c}\text { Individual households } \\
\text { Formal private }\end{array}$ & 20 & 83.3 & 29 & 87.8 & 28 & 68.3 & 6 & 37.5 & 10 & 76.9 & 8 & 61.5 & 101 & 72.2 \\
\hline $\begin{array}{c}\text { enterprises/ } \\
\text { manufactures }\end{array}$ & 4 & 16.7 & 2 & 6.1 & 13 & 31.7 & - & - & 3 & 27.1 & 5 & 38.5 & 27 & 19.3 \\
\hline Wholesalers/ retailers & - & - & 2 & 6.1 & - & - & - & - & - & - & - & - & 2 & 1.4 \\
\hline $\begin{array}{l}\text { State enterprises/ } \\
\text { manufactures }\end{array}$ & - & - & - & - & - & - & - & - & - & - & - & - & - & - \\
\hline $\begin{array}{c}\text { Informal sector } \\
\text { enterprise }\end{array}$ & - & - & - & - & - & - & 100 & 5 & - & - & - & - & 10 & 7.1 \\
\hline Total & 24 & 100 & 33 & 100 & 41 & 100 & 16 & 100 & 13 & 100 & 13 & 100 & 140 & 100 \\
\hline
\end{tabular}


The second but less significant source that induced demand for vendor produce came from formal private businesses like juice shops, residential house-based small-scale private restaurants, etc. The third less important source of demand came out of other informal sector units such home based prepared food sellers and other informal traders, etc.

When enquired to which income groups of households would they think of most often consume for their goods or services, 57.6 percent cited the low income groups, and 33.9 percent the middle income groups and 8.5 percent said the upper income households. Given that the major market for vendors came from individual households, the upward mobility of vendor business would depend on the rise of income of such individual household consumers. Over all, the consumption linkages with individual household incomes flooded vendors markets even though forward linkages with formal and informal enterprises were almost nil to induce demand for the products of street vendors.

\section{Consumption Linkage by Modern Formal Sector Wage Earner}

During the survey period, vendor entrepreneurs were asked to state whether modern formal workers were their customers or not. The result of the study is presented in Table 5.

Table 5: Distribution Consumption Linkages by Modern Sector Wage Earners.

\begin{tabular}{|c|c|c|c|c|c|c|c|c|c|c|c|c|c|c|}
\hline \multirow[t]{2}{*}{ Response } & \multicolumn{2}{|c|}{$\begin{array}{l}\text { Fruit and } \\
\text { Vegetable }\end{array}$} & \multicolumn{2}{|c|}{$\begin{array}{l}\text { Secondh } \\
\text { and } \\
\text { Cloth }\end{array}$} & \multicolumn{2}{|c|}{$\begin{array}{l}\text { Bicycle } \\
\text { Service }\end{array}$} & \multicolumn{2}{|c|}{$\begin{array}{l}\text { Prepared } \\
\text { Food }\end{array}$} & \multicolumn{2}{|c|}{$\begin{array}{c}\text { House } \\
\text { Hold } \\
\text { Goods }\end{array}$} & \multicolumn{2}{|c|}{$\begin{array}{c}\text { Miscella } \\
\text { neous } \\
\text { Activities }\end{array}$} & \multicolumn{2}{|c|}{ Total } \\
\hline & No & $\%$ & No & $\%$ & No & $\%$ & No & $\%$ & No & $\%$ & No & $\%$ & No & $\%$ \\
\hline Yes & 17 & 70.8 & 27 & 81.8 & 37 & 90.2 & 6 & 37.5 & 8 & 61.5 & 10 & 76.9 & 105 & 75.0 \\
\hline No & 7 & 29.2 & 6 & 18.2 & 4 & 9.8 & 10 & 62.5 & 5 & 38.5 & 3 & 23.1 & 35 & 25.0 \\
\hline Total & 24 & 100 & 33 & 100 & 41 & 100 & 16 & 100 & 13 & 100 & 13 & 100 & 140 & 100 \\
\hline
\end{tabular}

An inquiry into the consumption linkage with modern formal sector employees about $75.0 \%$ vendor respondents indicated modern formal sectors workers as their partners while only $25.0 \%$ replied they wouldn't.

Street vendors operations cannot exist in a total isolation from the modern employment. Therefore, formal sector wages have somehow determined the level of demand for street vendor goods or services. On the opposite side of a coin, at the markets that the modern sector is too high to reach, modern sector employees are relied on informal sector produce, i.e. street vending. As many as five types of enterprises cited formal employees as their customers excepting in case of prepared food vendors. Therefore, there was a symbiotic relationship between vendors and wage earners.

\section{Vendors Last Job before Vending and Labor/Work Mobility}

There is a significant mobility of labor from formal sector to informal sector units. As Figure 1 shows, both formal and informal sectors induce labor demand to vendor operations and street vending generally makes use of such a labor.

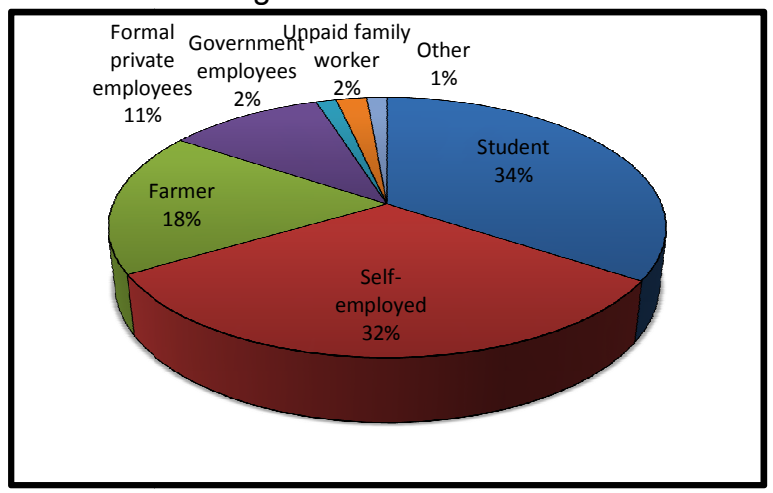

Figure 1: Vendors by the last job before vending. 
Habtamu Tolera

An attempt was made to relate vendor entrepreneurs' current activity with the past activity before vending. Accordingly, some proportions of vendors, i.e. $34.3 \%$ were students and street vending is so found to be essential for obtaining employment for primary school dropouts. Some $32.3 \%$ were self-employed informal sector operators in the same line of business sector economy and this reveals the prevalence of labor flows from other informal sector units to street vending. This denotes intrasectoral labor mobility. According to Sethuraman (1997) and Martha (2007), informal sector operators would be switched from the previous self-employment to other informal sector units to improve their skills and to work in a larger and potentially more lucrative market.

The evidence from the table also suggests that a great proportion among the rest vendor respondents who had work experience were engaged in agriculture, i.e. $18.0 \%$ of street operators were either farmers or farm workers. They were switched from the farm work due to the problems associated with traditional farming for very low returns and rural land scarcity. The labor transfer from private enterprises was $10.7 \%$. The corresponding proportion from government enterprises was very low. It was $1.4 \%$ only, which was nearly insignificant. Overall, $30.0 \%$ of street vendor operators in the study area were previously employed in the modern sector. This constitutes technological linkages. When compared vendors' present activities with the past activities, $56.2 \%, 42.2 \%$ and $41.7 \%$ of prepared food vendors, miscellaneous vendors, and fruit and vegetable sellers were students before joining vending profession respectively where as $53.8 \%$ of household goods vendor, $38.4 \%$ of miscellaneous vendors and $33.1 \%$ of fruit and vegetable sellers were self-employed in other informal sector units.
Sci. technol. arts Res. J., Jan-Mar 2013, 2(1): 95-102

\section{Competition over Factor and Product Markets}

During the field survey, operators were asked about the extent of competition in terms of markets for inputs and final products. Their responses are given in Table 6. Some $45.0 \%$ mentioned very high competition, which seems to indicate that they were feeling this pressure while $30.7 \%$ replied medium level of competition, and $9.3 \%$ low level of competition and the rest $15.0 \%$ said no competitions assuming that the areas surveyed was small when measured in terms of the purchasing power, it is fair to conclude that the extent of competition among venders or venders' activity was high in concentrating unit in the study area. One reason for this was perhaps the lack of innovativeness. If vendor entrepreneurs are willing to diversify their productive activities in areas where the potential has not yet been fully exploited and they are provided with the capacity to do so, their potential for growth would be improved and the risks associated with a homogenous portfolio came to reduce by this marketability force. Concerning the competition from formal merchants, they asserted that it is high both in product and factor markets. For example, vendors buy informally and sell at lower price than nearby public and private shops and outlets. This creates some conflict with formal traders.

\section{The Nature of Economic}

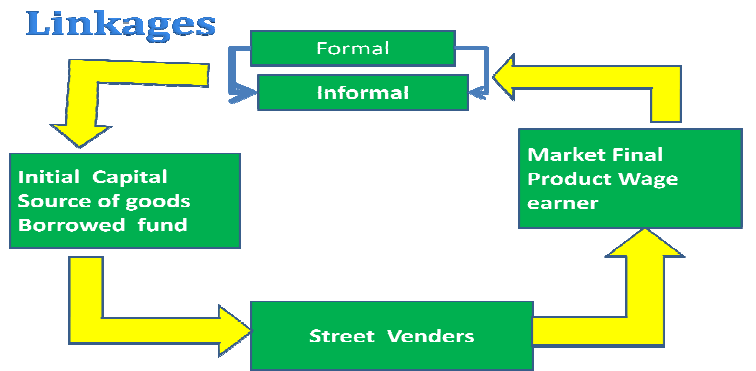

Figure 2: The Nature of Socio-Economic Linkages in the Study Area.

Table 6: Vendors by types of activity and their competition over market.

\begin{tabular}{|c|c|c|c|c|c|c|c|c|c|c|c|c|c|c|}
\hline \multirow{2}{*}{ Response } & \multicolumn{2}{|c|}{$\begin{array}{c}\text { Fruit } \\
\text { and } \\
\text { Vegetables }\end{array}$} & \multicolumn{2}{|c|}{$\begin{array}{l}\text { Second } \\
\text { Hand } \\
\text { Clothes }\end{array}$} & \multicolumn{2}{|c|}{$\begin{array}{l}\text { Bicycle } \\
\text { Service }\end{array}$} & \multicolumn{2}{|c|}{$\begin{array}{l}\text { Prepared } \\
\text { Food }\end{array}$} & \multicolumn{2}{|c|}{$\begin{array}{l}\text { House } \\
\text { Hold } \\
\text { Goods }\end{array}$} & \multicolumn{2}{|c|}{$\begin{array}{c}\text { Miscella } \\
\text { neous } \\
\text { Activities }\end{array}$} & \multicolumn{2}{|c|}{ Total } \\
\hline & No & $\%$ & No & $\%$ & No & $\%$ & No & $\%$ & No & $\%$ & No & $\%$ & No & $\%$ \\
\hline Very high & 11 & 45.8 & 16 & 48.5 & 21 & 51.2 & 6 & 37.5 & 5 & 34.4 & 4 & 30.8 & 63 & 45.0 \\
\hline Medium & 7 & 29.2 & 11 & 33.3 & 16 & 39.1 & 4 & 25.0 & 3 & 23.1 & 2 & 15.4 & 43 & 30.7 \\
\hline Low & 2 & 8.3 & 3 & 9.1 & 1 & 2.4 & 2 & 12.5 & 2 & 15.4 & 3 & 23.0 & 13 & 9.3 \\
\hline $\begin{array}{c}\text { No } \\
\text { Competition }\end{array}$ & 4 & 16.7 & 3 & 9.1 & 3 & 7.3 & 4 & 25.0 & 3 & 23.1 & 4 & 30.8 & 21 & 15.0 \\
\hline Total & 24 & 100 & 33 & 100 & 41 & 100 & 16 & 100 & 13 & 100 & 13 & 100 & 140 & 100 \\
\hline
\end{tabular}


Habtamu Tolera

\section{CONCLUSION}

The study investigates various types of economic linkages between street vending and formal and informal sector activities. These are backward, forward, consumption and technological linkages. In terms of backward types of linkages, the study reveals that 56.1 percent of vendor entrepreneurs obtained initial capital from formal sectors units. The study again found that there was nearly no closer linkage between vendor enterprise and formal financial institutions. The latter lent little loans to street enterprise owners. The survey also revealed the transfer of resource in the form of wage from wage earners to street vending. About 75.0 percent of vendors noted modern formal sector workers as consumers of their goods or services. Overall, the study suggests that a much larger proportion of the entrepreneurs sold their goods or services to individuals/pedestrians/ households suggesting that most of informal sectors traders dealt in goods or services consumed daily and the majority of street traders in the study could be found in this category. Finally, it is essential to integrate the vendor activities in the "kebele" local, city-level or regional development plan to ensure coherence of policies and strategies that are targeted at informal entrepreneurs. This is assumed to encourage informal vendors to be confidentially responsive to state policies and to facilitate economic linkages between sectors.

\section{REFERENCES}

Azeb Girma (1998). "Informal recycling in Mercato". Addis Ababa, ENDA-Ethiopia.

Bagachwa, M.D and Lauanga (1993). The state and the informal sector in Tanzania. ILO/JASPA.

Brommley, R. (1997). Working in the Streets: Survivals Strategy, Necessity, or Unavoidable evils? In: Cities in the developing world: issues, theory, and policy, edited by Josef Gugler. Oxford, England, Oxford University Press, 1997. 124-38.

Central Statistical Authority (2000). Report on urban informal sector sample survey, statistical bulletin, Volume320, Addis Ababa.

Central Statistical Authority. (2004b). Report on large and medium scale manufacturing and electricity industrial survey statistical bulletin, Volume 321 , Addis Ababa.

Chen A. Martha (2007). Rethinking the Informal Economy: Linkages with the Formal Economy and the Formal Regulatory Environment, department of Economics and Social Affairs, New York, USA.
Sci. technol. arts Res. J., Jan-Mar 2013, 2(1): 95-102

De Soto, H (1989). The Other Path, Harper and Row, New York.

Etsegenet Abebe (2001). The survival and growth of micro-enterprises in Ethiopia.

Fowler, A. (1981). The informal sector in Freetown and opportunities for self- employment in Geneva.

Getachew Minas (1994). The informal sector enterprises: The dynamics of linkages under policy reform in Getachew Yoseph and Abdul Hamid bedri Kello (Eds).

Granström C Sigrid (2009). The Informal Sector And Formal Competitiveness in Senegal, Department of Economics at the University of Lund.

Habtamu Tolera (2006) An Assessment of Informal Sector in sustaining Urban Livelihoods, AUU, Ethiopia.

ILO (1985). Informal sector in Africa, Addis Ababa.

ILO (1991). "The dilemma of the informal sector." International Labor Conference, $78^{\text {th }}$ sessions, Geneva.

ILO (1984). The informal sector in Africa: synthesis and country summaries, Addis Ababa.

McGee, T. (1986). On the utilization of dualism: The informal sector and Mega urbanization in Southeast Asia.

McGee, T. G. and Yeung, M (1977). Hawkers in South East Asian Cities: Planning for Bazaar.

Moser, C (1978). The informal sector or petty commodity production: Dualism or dependence in poverty and environment; ILO, Geneva.

Rempel, H. (1996). "Rural to urban migration and urban informal activities, RDD", Vol 17(1). 97.

Robert, R. B. (1989). Employment structure, life cycle and life chances: Formal and informal sector in Guadalajara in Portes, Castells and Benton (Eds). The informa economy.

Sethuraman (1997): The urban informal sector in developing countries. Employment.

Tesfaye Wolde (1999). Employment and income in the urban informal sector; AAU, Ethiopia.

Todaro, P. M. (1994). Economic development (5th Ed). New York University Press, London.

Webister, L. and Fidler, P (1996). The informal sector and micro-finance institutions in West Africa. 